\title{
REFLEXIONS SOBRE L'EXPERIMENTACIÓ POÈTICA \\ DE JOAN BROSSA I LA TRADUCCIÓ \\ DELS PROCESSOS INCONSCIENTS
}

\author{
MERCÈ ALTIMIR LOSADA
}

\begin{abstract}
This paper analyses Joan Brossa's experimentation with hypnagogic images and, at a later stage, letters (object and visual poems). In the process it attempts to put forward some general thoughts on man's relationship with language, a problem that directly involves translation and the concept of equivalence in translation. Using the work of Freud as a guide, I explore the origins of the debate on the phenomenon of hypnagogic images. I then look at Lacan's concept of the "letter" (lettre) in seeking to gain an understanding of some of Brossa's output and of the existence of a wall in translation.
\end{abstract}

\section{ESCRIURE I OBLIDAR}

Una de les dites recurrents i sovint citada de Joan Brossa és "oblidar i caminar". En una entrevista que va fer-li Jordi Coca l'any 1982, el poeta, que aleshores tenia 73 anys, va explicar:

En allò que crec és a no deixar racons. Jo voldria tenir una ànima sense racons, que tot estigués a la vista. Les vivències, cal treure-les i després deixar-les estar. Una de les coses que més m’agraden és oblidar. El mecanisme de l'oblit és la higiene de la persona. Per viure tranquil s'ha d'oblidar i caminar. (122)

Que delicadament freudià! Prenem aquest comentari com a fil conductor, entre molts d'altres possibles, d'un recorregut per força parcial a través d'algunes produccions de l'extensa obra brossiana. Desades ja les perruques, els (auto) enganys, les fantasies i les il-lusions (imposades pels altres) - en definitiva, tot allò que fa nosa i convé llençar a les aigües del Leteu-, hauria de romandre tan sols l'essencial. Allò que potser simbolitza la lletra "A", per tal com és la primera lletra de l'alfabet, el nostre sistema gràfic des de fa una colla de segles? La sendera artística esdevé pas a pas l'estret camí de la vida. Donats els topants de la nostra condició humana, la construïm a través i gràcies a les paraules (textuals, visuals o escèniques).

Ens sembla, però, que, en aquesta sentència tan clara i definitòria d'una ètica personal, el poeta no va encertar l'ordre dels sintagmes. No és que l'oblit ens meni 
a l'escriptura, sinó a l'inrevés, per tal com és l'acte d'escriure, sempre que estigui orientat per l'honestedat amb nosaltres mateixos, el que fa possible la distància i l'oblit. Des de les imatges hipnagògiques dels inicis a les lletres d'anys posteriors, un mateix impuls i una necessitat constant d'encarrilar la fúria i el neguit encenen i guien el treball de l'escriptura. Cal, però, filar prim i jugar net, perquè tant podem ser artífexs del bon oblit com relliscar en el trampós, el de la censura, que s'eternitza en la repetició. Es pot caminar molt i no moure's de lloc.

A Contextos de Joan Brossa (2010), John London ens convida a "obrir-nos a noves lectures" i a la "possibilitat d'altres interpretacions" (21). Justament és el que ens guia en aquest intent d'apropament a algunes de les produccions de Brossa des d'una perspectiva psicoanalítica. En acabat, mirarem de respondre a la pregunta sobre la relació entre l'escriptura com a camí i l'oblit.

Alhora, aquesta proposta es justifica pel fet que Brossa va ser un lector apassionat de Sigmund Freud, així com també de Carl Gustav Jung. Les imatges hipnagògiques, com veurem, sorgeixen per primer cop a l'edició de 1914 de $\mathrm{La}$ interpretació dels somnis. "L'inconscient té l'estructura d'un llenguatge" (Lacan 1973), diu anys després el psicoanalista Jacques Lacan i fa emergir de nou a la llum clara del pensament el descobriment freudià, que una lectura estereotipada, gandula i gastada havia enfosquit. I encara ens cal remarcar i insistir en un altre aspecte. Aquesta xarxa de text, que la consciència desconeix, s'alimenta de sang i de foc: "Em bull al pit una teia portentosa" (Brossa, "Model de fruita" 23). Això significa que no la podem diluir, obeint el llegat de l'estructuralisme, ni a un simbolisme abstracte ni a simples cadenes i sistemes de signes lingüístics que neixen i creixen en el buit de la passió, com si es tractés d'un mer exercici intel-lectual. La llengua i l'escriptura, en definitiva, no són independents del nostre cos d'animals enraonadors.

Màgic cinema

Poso cigarret.

M'apropo a vosaltres

Amb el mot escrit

I em faig donar foc de debò.

Vosaltres

Em doneu un mocador i vet aquí

Que el mocador inexplicablement

Us desapareix de les mans

Per trobar-se escrit en aquest

Paper.

Tot seguit

Poso cadira, i heus 
Aquí que teniu a les mans

Una cadira veritable.

Finalment

Jo entro al poema,

I aquí em teniu projectat

Tot sencer.

“Màgic cinema” (Brossa, El Saltamartí, 81)

El mot i el referent juguen a intercanviar el lloc, a la manera de Magritte. A la darrera estrofa, és la veu del poeta allò que ha esdevingut una presència feta de paraules. En el comerç textual diari, qui s'adona del fet que un text és l'aparició d'una veu per força absent i, per consegüent, intraduïble? L'exercici verbal del poema ens fa pensar en un altre dels matemes de Lacan: "un significant és allò que representa un subjecte per a un altre significant" (Lacan 1966). Tan aviat com parlem, ens eclipsem rere les paraules que tot just acabem de pronunciar. La matèria fònica encadenada és l'únic índex de la nostra existència, incopsable, de subjecte. Però sembla encara que som davant d'un problema merament cognitiu, i no és així.

L'impacte del llenguatge sobre el cos va transformar el que hauria estat l'instint animal en una astoradora deriva pulsional, en un desori de forces obscures que busquen una perillosa satisfacció immediata. Això ens obliga a realitzar un treball forçat d'apaivagament i de reconducció (lúdic i pagat, si hi ha sort) que ha d'ajudar a contrarestar el poder d'aquest imant inquietant. Manuel Sacristan, al pròleg que va escriure per a Poesia Rasa (1970), fa esment de l'angoixa, el signe indubtable de la presència real del cos, oculta rere les paraules: "Sempre torna Brossa, algun dia de cada any, a jugar amb inquietants facècies rítmiques, amb irreprotxables odes o sonets corrosius, sardònics, que, al mateix temps que netegen i destrueixen, deixen en el lector la sospita de ser també, involuntàriament o molt volgudament, angoixada poesia sobre la poesia" (15).

La certesa caracteritza i distingeix l'angoixa d'altres sentiments més mentiders. L'odi, la indiferència o l'amor equivoquen cada dos per tres tant el destí objectual com la verdadera qualitat afectiva. Fan gala del joc de prestidigitació que va estimar Brossa, tot i que amb intensitat semblant desconfiés de les paraules. Odi en comptes d'amor, amor en comptes d'odi, indiferència que (ens) oculta la passió... Fins al punt que Freud, sorprès, va escriure l'any 1920:

No quiero dejar pasar la ocasión de manifestar mi asombro ante el hecho de que los hombres puedan vivir fragmentos tan amplios y significativos de su vida erótica sin advertir gran cosa de ellos e incluso sin sospecharlos lo más mínimo o se equivoquen tan fundamentalmente al enjuiciarlos cuando emergen en su conciencia. ("Sobre la psicogénesis de un caso de homosexualidad femenina" 2557) 
Al contrari dels sentiments, l'angoixa és dreturera, no dóna gat per llebre. Confrontat el misteri de l'emoció estètica, a El pensament salvatge (1985) Claude Lévi-Strauss va proposar-ne una explicació força interessant. L'esforç de l'artista aniria adreçat a l'intent de transformar una realitat inabastable en un model reduït que, en endavant, el seu creador podria manipular en la direcció que més li convingués. A tall d'exemple, esmenta la minuciositat i el detallisme de la gorgera de randa pintada per Clouet o les pintures de la Capella Sixtina, les quals, tot i la grandària impactant, resulten insignificants si se les compara amb la idea colossal de l'apocalipsi que representen (65).

L'obscur anhel matern (mític, d'altra banda) és la força més pertorbadora i extrema amb què es confronta l'ésser humà. Aquesta situació primera d'esclavatge passiu retorna en tots els moments de desengany i d'abandó: "Tu poses la capitana sang a la paraula d'aquests nous poemes" (Brossa, "Model de fruita" 24). L'única escapatòria és capgirar-la a través de l'acció i de l'acte de fer-la conscient.

JÚLIA

La jota és la jota de juny

La u és la u d'Urània.

La ela és la ela de lila.

La i és la i d'imanta.

L’a és l'a d'aurora.

I no m’arrancareu d'aquesta base.

“Cant” (1954) (Brossa Poesia rasa 313)

Dolors Oller cita aquest poema com un exemple de "l'ús paradoxal de la realitat" que empra Brossa. Incideix en el fet que el lirisme dels mots escrits en cursiva - dels quals el poeta n'ha extret la inicial per tal de confegir les lletres del nom del subjecte femení- fan un contrast anacrònic amb l'expressió objectiva del sentiment (45-47). La dama ha quedat reduïda (de manera semblant al que succeeix amb el cap de l'enemic a mans del guerrer victoriós entre alguns indígenes) a una maqueta feta de mots i d'inicials de mots... Això és tot? No hi percebem, rere la "facècia sardònica", la lluita angoixada per la supervivència, una escriptura enfurismada a la recerca de l'oblit?

A Brossa $x$ Brossa (1999), el poeta ens fa partícips del record dels terrors i malsons infantils. El nen va tenir un ensurt dels grossos el dia que va ensopegar amb un ninot mutilat descobert en una cambra de mals endreços. La figura esgarrifosa li retornava en somnis. Però encara tenia més por d'algunes paraules estranyes (24). Per contrarestar aquests nocturns visitants aterridors, inventava noms (combatia el pànic amb l'ànsia creadora):

Jo tenia la mania de posar motius a les persones, amb noms que m'inventava; em sortien 
espontàniament, sense rumiar gens. Per exemple, a l'oncle banquer: "el tiet Puesxola"; l'àvia: "Míster Iden Iu mejorcitu gluriós"... . Ja eren com una mena de poemes, oi? (25-26)

Ja de gran, a l'època de Dau al set, va agafar el costum de batejar els quadres dels amics Antoni Tàpies, Joan Ponç i Modest Cuixart:

Els primers quadres que vaig batejar van ser els seus [els de Tàpies], però no recordo si va ser ell qui m'ho va demanar. Vaig posar títols com ara El bateig de Wotam, El jardí de Batafra, etc. Després vaig fer el mateix amb Ponç i amb algun de Cuixart, com és ara Mascro. Era com fer poemes, però per un altre camí; m’interessava molt buscar els noms exòtics que em suggerien els quadres. El títol no el posava immediatament; per exemple, Tàpies, una vegada llestes les obres, me les ensenyava i jo li portava els noms l'endemà. Els havia de rumiar. En aquella època havia fet una mitologia, amb tots els déus imaginaris i sortien aquesta mena de noms: per exemple, el meu Batafra correspon a Wotam. (121-122)

Freud, en un breu escrit anterior al seu descobriment, "Tratamiento psíquico (tratamiento del alma)" (1890) explica que les paraules incolores que utilitzem habitualment tenien, fa molt de temps, una poderosa força màgica. A Brossa, Salvador Aulèstia el va advertir que anés amb compte amb alguns dels usos que feia dels mots perquè podien representar un perill (Permanyer 92-93). Comparades amb les dels homes corrents, hi ha antenes més sensibles al món del somni i de la màgia.

A l'època d'Algol, 1946, i de Dau al set, 1948-1951, els integrants del cercle d'artistes que envoltaven Brossa estaven tocats per la dèria de les forces obscures. L'evocació del diable a Algol porta a la memòria el vers de Virgili amb què Freud va encapçalar l'edició de 1899 de La interpretació dels somnis: "Flectere si nequeo superos, acheronta movebo".

A "Diàbolo" (1945), Brossa escriu: "Li he buscat el cor durant anys i anys. Tot ha influït damunt tot. Si els meus dies favorables són dimarts i dissabte; si entre gener i febrer, Taure: què em costa de treure-la a ballar!" (Prosa completa $i$ altres textos 86). I a "La presència forta" (1946): "Deixeu que el maligne us devori amb els ulls, eixit bruscament del mar, per tal que la seva faç, d'una sentor violeta, resplendeixi com mai cap porcellana no ho ha aconseguit" (88). El fragment de "Diàbolo" remet a la relació angoixada amb la dona. Al segon fragment citat, l'evoca de nou. En aquest cas, com a la coneguda pintura de Botticelli, transformada en una Venus fetillera i diabòlica emergint de les aigües. Una bella impostora que dissimula el parany paorós d'un remolí marí. El mar, justament, és un dels elements freqüents dels sonets de "La bola i l'escarabat" (1941-1943), el primer recull de Brossa on incorpora les imatges hipnagògiques.

Volem dir, en definitiva, que l'encontre amb l'inconscient no és ni intel-lectual ni emocionalment anodí, no és un afer purament textual. És un cara a cara amb la 
pulsió, que és inscrita al cos a la manera d'unes lletres lliures i deslligades. Per fer-la enrere, per redreçar-ne la força, cal enfrontar-la i lluitar. Brossa la va combatre amb l'arma de l'escriptura poètica.

\section{LES EXPERIMENTACIONS DE L'INICI AMB LES IMATGES HIPNAGÒGIQUES}

Segons explica el mateix Brossa, les seves primeres experimentacions amb l'escriptura, a banda del text que va escriure i signar al front del Segre a les acaballes de la guerra, van ser les imatges auditives i visuals provinents de l'inconscient que, ja de retorn a Barcelona un cop finalitzat el servei obligatori amb l'exèrcit de Franco l'any 1940, anotava en unes llibretes. Què l'havia dut a aquesta pràctica i què l'havia inspirat? La resposta no és simple, com mirarem d'argumentar. Per un costat, Enric Tormo va ser una influència cabdal durant aquest període d'aprenentatge. Va ser ell qui va descobrir-li tant Tagore com els poemes d'avantguarda de Salvat-Papasseit (Permanyer 65). De l'altre, la lectura del llibre de Teodoro D. Soria y Hernández, Lecciones de psicología (1935), el va esperonar a capbussar-se en les obres de Freud i de Jung, els dos grans psicòlegs del segle passat. D'entrada, volem dir que, fos quin fos l'itinerari de lectures, aquestes experimentacions li van permetre de seguir el combat encetat a la infantesa contra unes imatges d'estranya i pertorbadora intensitat.

Un dels problemes que se'ns plantegen és saber exactament quan comença Brossa a emprar la denominació "imatges hipnagògiques" per referir-se als seus primers exercicis. Ja emprava aquest concepte abans de conèixer Foix o abans de tenir coneixement dels seus escrits? Quan va succeir això? Si hem de confiar en el que diu a les entrevistes que va fer-li Jordi Coca, no havia llegit Foix, que és qui va introduir el terme, abans de tenir-hi la primera entrevista:

— El 1941 coneixes Joan Miró. ¿Va ser aquest el primer contacte directe amb el món que intuïes?

- No, de primer vaig conèixer en Tormo, l'únic a qui jo vaig confiar aquests exercicis que feia. Em va confessar francament que ell no sabia ben bé per on anava i em va comunicar amb un amic seu, Manuel Viusà, que em va dir: "Home, jo no sé què pretens, però conec una persona que és l'única que et pot orientar. Vés amb compte, que té mal geni. No li diguis que em coneixes". I aquest era en Foix. (Coca 22)

Si les experimentacions que anotava a la llibreta són anteriors a la coneixença de Foix, no seria massa casual que, abans que això es produís, les hagués anomenades imatges hipnagògiques? Ara bé, hi havia una extensa tradició documental sobre 
aquestes imatges. En cas que Brossa hagués consultat algun número de la revista L'Amic de les Arts d'abans de la guerra o algun dels escrits de Salvador Dalí del mateix període, les havia d'haver conegut per força.

Ramon Salvo (1995) i Vicent Santamaria (1999) expliquen que va ser Foix qui primer va emprar el concepte d'imatge hipnagògica dins la literatura catalana. En va parlar a la conferència a Sitges de 1928. I aquest mateix any, a la revista L'Amic de les Arts, va fer explícita la seva posició amb una explicació que, de fet, era una traducció de fragments de Les Visions du démi-sommeil, un llibre d'Eugène Bernard Leroy publicat l'any 1926 (Santamaria 11). Es tracta, concretament, d'imatges provinents del somieig diürn.

A parer de Salvo, J.V. Foix fixa el concepte d'imatge hipnagògica i marca la distància entre aquesta i l'escriptura automàtica del surrealisme francès. Això el du a afirmar que "[és] la imatge hipnagògica, i no pas l'escriptura automàtica, la base sobre la qual treballen J.V. Foix i Joan Brossa, i la imatge hipnagògica és, per tant, el fonament sobre el qual s'ha bastit la poesia catalana — a excepció de la de Dalí - lligada al Surrealisme" (Salvo, s.p.).

Vicent Santamaria (1999) ha exposat amb molt de detall l'origen de l'ús de la imatge hipnagògica tant dins dels cercles artístics i literaris parisencs com a casa nostra. En el primer cas, l'iniciador va ser André Breton:

D'entre els diferents tipus possibles de visions constatats per psicòlegs i psiquiatres, Breton, des del començament de la seva activitat surrealista, parà esment, d'una manera especial, en aquelles visions esdevingudes a la vora del somni, en les visions del presomni altrament anomenades hipnagògiques. (10)

La font principal de Breton va ser un llibre d'Alfred Maury, Le sommeil et le rêve, publicat l'any 1861 (11). Maury és un autor citat també diverses vegades a La interpretació dels somnis.

Pel que fa a Foix, no només va llegir amb avidesa els avenços de l'avantguarda duts a terme fora del país. Alhora estava molt al corrent de les novetats editorials sorgides en el camp de la psiquiatria i de la psicologia. A Freud el llegia en francès (Santamaria 18). ${ }^{1}$

Una conclusió, doncs, és que l'entrada de la imatge hipnagògica dins la experimentació literària, tant a França com a Catalunya, es va fer a partir de treballs psiquiàtrics i psicològics que podem categoritzar principalment de descriptius. No hi ha punt de comparació amb la complexitat i l'abast de l'obra de Freud. Ara bé, sabem que tant Foix com Dalí, així com més tard Brossa, van sovintejar-ne la lectura. Quins rastres va deixar en les seves obres literàries? Resoldre aquesta pregunta demanaria un altre estudi.

Un fet interessant és que Leroy va brindar els seus exemples en forma d'anotacions fetes a la manera d'un diari personal (Santamaria 12), i això mateix 
és el que va fer Brossa els primers anys de la dècada dels 40 (d'altra banda, és el procediment seguit per Freud amb els somnis propis).

Una altra possibilitat és pensar que Brossa va recollir la idea de les imatges hipnagògiques directament del llibre de Soria y Hernández. Aquesta hipòtesi ens sembla aventurada, donat que, a qualsevol que consulti el llibre, ha de resultar-li evident que el registre del fenomen de les imatges oníriques ocupa un lloc d'interès indubtablement superior al corresponent a les imatges hipnagògiques.

Es fa difícil escatir si el que anotava Brossa a les llibretes des de l'any 1940 i durant els anys següents eren realment imatges hipnagògiques, el record d'imatges oníriques, o totes dues coses. A Brossa X Brossa comenta:

La lectura de Freud, l'altre gran descobriment [a més de la lectura del monogrà fic de 1934 de D'Ací i d'Allà i de Jung, suggerides per Tormo], m'acostà, entre altres coses, al món dels somnis i al de les imatges hipnagògiques. Des de llavors, i encara ho faig ara, quan em desperto estic una estona tractant de recordar el que he somniat $i$ analitzant-ho, perquè fins llavors jo els havia interpretat segons el que deien els llibres de màgia, que és d'un to més aviat pintoresc. Freud em situà en la pista per entendre-les. (66)

No parla ni d'escriptura automàtica ni de visions hipnagògiques, sinó de l'anotació metòdica del que recorda de les imatges dels somnis de la nit, que és el tema central de La interpretació dels somnis.

El llibre del catedràtic de filosofia Teodoro D. Soria y Hernández és una mena de manual de psicologia general força insuls. Amb tot, ens interessa llegir-lo amb els ulls de Brossa, perquè, en una època en què, segons confessa, poques lectures el van encuriosir, Lecciones de psicologia el va fascinar: "Veia que la literatura anava molt lligada a la psicologia i em vaig posar a estudiar-ne" (Coca 21). A la introducció hi llegim la importància que dóna al moviment com a conducta específicament humana:

Es el hombre uno de los numerosísimos seres que en el mundo son. Está en un espacio donde coexiste con los demás seres, de los cuales unos son diversos de él y semejantes a él otros; él mismo es numérica, individualmente múltiple. Carácter suyo y básico, por cierto, es el que vive, que se mueve de y por sí mismo. Este movimiento peculiarísimo que es su vida, está determinado, orientado por y hacia situaciones, o sea las relaciones innúmeras y constantes que surgen del hecho de estar en un espacio de propiedades múltiples y cambiantes, del hecho de coexistir en ese espacio con unos seres y convivir con otros: cambia de lugar, desplaza sus miembros, se incorpora cosas distintas de él, respira, digiere, se nutre y crece, conoce... Conocer es, pues, una de las manifestaciones del vivir humano, una de las formas de ejercitarse esa actividad, ese movimiento, de que es principio y manantial el hombre. Se caracteriza por ser "una aprehensión, una apropiación espiritual de algo que existe independientemente del conocimiento". (Soria y Hernández 5) 
Brossa hi va copsar, sens dubte, la idea de transformació del seu admirat Frégoli. Les imatges hipnagògiques s'esmenten al capítol XXXI, "Estados psíquicos”:

... el hombre, como vida organizada, se nos ofrece en situaciones diversas, en las que el contenido psíquico y las funciones psíquicas, su engranaje y trama en la unidad compleja del yo y su proyección - comportamiento, conducta - en el mundo presentan caracteres peculaires. Estas situaciones son las que denominamos estados psíquicos. (209)

Un d'aquests estats es el de "duermevela". Són moments en què:

Los umbrales sensoriales se elevan, pierden las sensaciones su poder evocador de imágenes implicadas y van predominando las imágenes libres —imágenes hipnagógicas-, la sistematización perceptiva se desorganiza, el mundo exterior va perdiendo significado y la conciencia de sí mismo va nublándose y decreciendo el poder de adaptación. (210)

Aquestes són les seves característiques:

1) Són imatges lliures (pseudoal-lucinacions), principalment auditives i visuals (211). El concepte d'imatge lliure és fonamental. En el pensament lògic i gramatical, les imatges són unitats elementals (abstractes; recordem que, per a Saussure, el significant és una imatge sonora o una imatge visual), que es caracteritzen per la seva insuficiència. Això fa que necessitin l'encadenament amb d'altres (seguint l'eix paradigmàtic i sintagmàtic). Aquestes imatges, en canvi, no fan cadena.

2) Són imatges inestables i plenes de moviment (210).

3) Apareixen a l'atzar, inesperadament (211).

4) Es diferencien de les del somni ("ensueño") pel fet que "el sujeto sigue en contacto con el mundo exterior y se mantiene capaz de movimientos voluntarios; no obstante la imagen hipnagógica puede conducir al sueño — ese es el significado de su nombre- y convertirse en ensueño" (211). És a dir, poden ser provocades per un acte voluntari, i això les diferencia dels lapsus $i$ dels actes fallits en general.

Veurem que Freud les qualifica de manifestacions de la instància de la censura dins l'estructura psíquica del jo. Al llibre de Soria y Hernández les explicacions no ocupen ni la meitat d'extensió de l'espai concedit a les imatges oníriques. A continuació, es tracta d'explicar l'origen d'aquest concepte d'imatge hipnagògica dins el context del pensament de Freud i algunes de les controvèrsies que va protagonitzar.

El fundador de la psicoanàlisi les esmenta en diverses ocasions, juntament amb el seu suposat descobridor, Herbert Silberer (1882-1923), a La interpretació dels somnis. La data de la primera publicació d'aquesta obra fonamental és l'any 1899 , però s'ha de saber que no és fins l'edició de 1914 que l'autor incorpora el concepte. ${ }^{2}$ 
El llibre de Leroy parafrasejat per Foix és, per tant, posterior. El de Maury, en canvi, és anterior fins i tot a la primera edició.

Silberer va néixer a Viena i semblava destinat a seguir les passes del seu pare, una figura eminent del món de l'esport. L'any 1923 es va suïcidar. Es va apropar al cercle de Freud - en aquells anys integrat per un reduit nombre de deixebles i col-legues - amb el propòsit de resoldre problemes personals i va acabar exercint la pràctica de la psicoanàlisi. Freud va recomanar la inclusió d'un treball de la seva autoria, "Rapport sur une méthode permettant de provoquer et d'observer certains phénomènes hallucinatoires symboliques", al número inaugural de la que va ser la primera revista oficial de la psicoanàlisi, el Jahrbuch für psychoanalytische und psychopatologische Forschungen. ${ }^{3}$

A continuació citem un comentari de Freud que fa referència a la naturalesa i a la rellevància de les imatges hipnagògiques dins el context de l'activitat de la "elaboració secundària", un mecanisme de camuflatge molt proper al jo censor (es tracta d'una instància de vigilància que té l'objectiu d'evitar que el pensament censurat es faci visible a la consciència): ${ }^{4}$

Al estudio de la elaboración secundaria añadiré el de una nueva aportación de la elaboración onírica, descubierta por las sutiles observaciones de H. Silberer. Este investigador ha logrado sorprender in fraganti, como ya lo indicamos en otro lugar, la transformación de ideas en imágenes, forzándose a una actividad intelectual en ocasiones en las que se hallaba muy fatigado o medio dormido. En estos casos se le escapaba la idea elaborada y surgía en su lugar una visión que demostraba ser una sustitución de la idea más abstracta. En estos experimentos sucedió que la imagen surgida, equivalente a un elemento onírico, no representaba la idea sometida a la elaboración, sino algo distinto: la fatiga misma, la dificultad que entrañaba la labor propuesta o el disgusto por tenerla que llevar a cabo; esto es, el estado subjetivo o la forma funcional de la persona que se imponía el esfuerzo mental en lugar del objeto del esfuerzo. Silberer dio a este caso, muy frecuente en él, el nombre de "fenómeno funcional", para diferenciarlo del fenómeno material esperado. ( $\mathrm{La}$ interpretación de los sueños 653)

A continuació cita alguns exemples de percepció endopsíquica. En reproduïm un: "Circunstancias: Quiero permanecer todavía en la cama, pero sin dormirme. Escena: Me despido de alguién y quedo en volver a verle pronto" (653). A l'exemple es pot percebre com un pensament abstracte es transforma en imatges, tal com succeeix també en l'escenografia onírica. ${ }^{5}$

Unes línies més avall, critica —i és una al-lusió a Jung — l'abús de la interpretació simbòlica de les imatges hipnagògiques. Insisteix que no es tracta d'una activitat de pensament sinó, simplement, de "romanalla del dia anterior":

El interesantísimo fenómeno funcional de Silberer ha sido causa de grandes errores — claro está que sin culpa alguna por parte de su descubridor-, pues la antigua tendencia a la 
interpretación simbólica abstracta de los sueños ha creído hallar en él un firme apoyo. La predilección por la "categoría funcional" llega tan lejos en algunos investigadores, que les hace hablar de fenómeno funcional siempre que en el contenido de las ideas latentes aparecen actividades intelectuales o procesos sentimentales, aunque este material tiene el mismo derecho que todo el restante a entrar en el sueño a título de resto diurno. (654)

Anys més tard, les imatges hipnagògiques funcionals faran una altra contribució capital a la comprensió del funcionament psíquic. Freud ens ho explica al treball fonamental de 1914, Introducción al narcisismo:

Será muy interesante hallar también en otros sectores indicios de la actividad de esta instancia crítica observadora, elevada a la categoría de conciencia y de introspección filosófica. Recordaré, pues, aquello que H. Silberer ha descrito con el nombre de "fenómeno funcional" y que constituye uno de los escasos complementos de valor indiscutible aportados hasta hoy a nuestra teoría de los sueños. Silberer ha mostrado que, en estados intermedios entre la vigilia y el sueño, podemos observar directamente la transformación de ideas en imágenes visuales; pero que, en tales circunstancias, lo que surge ante nosotros no es, muchas veces, un contenido del pensamiento, sino del estado en el que se encuentra la persona que lucha con el sueño. Asimismo ha demostrado que algunas conclusiones de los sueños y ciertos detalles de los mismos corresponden exclusivamente a la autopercepción del estado de reposo o del despertar. Ha descubierto, pues, la participación de la autopercepción —en el sentido del delirio de la observación paranoica- en la producción onírica.

... Recordaremos haber hallado que la producción onírica nace bajo el dominio de una censura que impone a las ideas latentes del sueño una deformación. ... Penetrando más en la estructura del yo, podemos reconocer en el yo ideal y en las manifestaciones dinámicas de la conciencia moral este censor del sueño. (2030-2031)

El suposat simbolisme dels somnis va ser un dels punts de fricció entre Freud, Silberer i Jung. L'any 1901, Silberer va fer el seu ingrés a la Societat Psicoanalítica de Viena, però el seu interès es va decantar cada vegada més cap a la mística i l'esoterisme (l'any 1914 va escriure Probleme der Mystik und ihrer Symbolik). Els punts de vista de Silberer i Freud en relació als somnis van anar allunyant-se gradualment. El primer proposava una "interpretació anagògica", és a dir, allunyada de la referència sexual. És la mateixa postura que va adoptar Jung. Aquest darrer va reconèixer el deute contret amb Silberer a l'epíleg de Die Konjunktion (1955-1956): "El mèrit del descobriment dels fils secrets que discorren de l'alquímia a la psicologia correspon a Herbert Silberer, desaparegut, malauradament, abans d'hora" (citat a Mijolla 1576). Tal com es pot apreciar pels comentaris precedents, va existir una forta controvèrsia en relació a les imatges hipnagògiques al seu territori psicològic d'origen. Les imatges oníriques, per a Freud, no són símbols universals. ${ }^{6}$ Justament, en cas que així fos, seria possible pensar en la possibilitat 
d'una una traducció sense pèrdues perquè existiria una llengua universal subjacent. A banda del que puguem deduir a partir de la seva escriptura, desconeixem què va llegir Brossa exactament ni a quines conclusions va arribar. En el comentari següent hi percebem un ressò tal volta més junguià que freudià:

Una concentració de llenguatge i un assaig de correspondències. El valor d'un poema el determina el nombre de finestres que obre al lector. La imatge poètica és vàlida quan estableix un lligam profund entre el símbol i la veritat psíquica. Si no és així el poema es converteix en una endevinalla formal. En una fotuda abstracció. (Permanyer 48)

Ara bé, indica clarament que sense la connexió amb l'inconscient ("la veritat psíquica" desconeguda) l'escriptura no té cap valor. Com veurem més endavant i tal com adverteix London (167-68), les lletres-objecte són un darrer atzucac on Brossa verifica la impossibilitat del símbol universal, objectiu i unívoc. És a dir, aliè a una llengua concreta i a la singularitat del dir de cada subjecte: tan allunyat de la traducció com els senyals de trànsit de la carretera, que per això són tan pobres com a forces generadores de significació.

Ramon Salvo (1995) ha publicat les experimentacions que Brossa va anotar en dues llibretes. Després de dormir durant dècades, havien estat feliçment retrobades. Entre les notes desades, n'hi ha de prou "entenedores": "Els freds esclaten", "A penes mínim m’humanitzo", (21 de gener de 1942); "És l'hora caiguda dels dubtes excelsos" (27 de gener de 1942); "El diable mor en dona (3 de febrer de 42)"; com d'interrompudes: "A la cabana tan afrosa i imprevista", "A favor de les prolongacions d'Isolda" ( 3 de febrer de 42 ). N'hi ha d'altres que trenquen del tot l'ordre gramatical de la frase: "Llavors capirem vessar d'ordre boscúria" (19 de gener de 42), "La vaig veure l'abella es fa" (21 de gener de 1942). Val a dir, que a una gran part i gràcies al subterfugi d'introduir-hi unes petites modificacions, podem tornar-les intel-ligibles. Per exemple, "Arsenal dels llibres només rosa només tinta" (4 de gener de 42) guanya en comprensió si hi inserim una escansió: "Arsenal dels llibres / només rosa només tinta". La següent, si hi inserim un mot: "Aquesta placeta de noces era (camp) de batalla" (3 de febrer de 42), etc. (Salvo s.p.).

També en el cas de "Poema", de 1943, la sintaxi és prou clara i ja hi llegim el tema dels inferns dels anys següents: "Arbres de nadal cap al diable / ombregen palanganes al meu neguit / Cors amb sordines de braços / musiten l'espès minuet del so que trepitgen" (Salvo, s.p.).

Es fa difícil, a partir d'aquestes primeres produccions, esbrinar si Brossa aprofitava imatges oníriques recordades o es tractava més específicament d'imatges recollides en el moment d'endormiscar-se o provocades. Però el que sí que podem afirmar és que el poeta, seguint en això la crida de l'avantguarda històrica, va sentir la necessitat de sacsejar la llengua ordinària, el funcionament del signe lingüístic tal com el descriu la ciència de Saussure. Li va ser necessari, ni que fos com a 
etapa transitòria, barallar-se amb la llengua social imposada. Era una estratègia encaminada a connectar amb una realitat desconeguda i, no obstant, no menys real. Com afirma Glòria Bordons, “aquests processos li serviren per expressar el seu món interior mitjançant la materialització verbal d'unes visions extretes del subconscient" (305). Bordons afegeix que, en introduir aquestes experimentacions al sonet — per començar, a La bola i l'escarabat (1941-1943)_, seguint els consells de Foix, el lligam entre les imatges recupera una ordenació sintàctica. Només a Malviatge! (1954) retorna a la manca de puntuació i a la ruptura gramatical. Però va tractar-se només d'un episodi temporal (313).

Foix li va aconsellar de no maltractar massa una llengua que, a diferència de la francesa, era feble i es trobava en fase de reconstrucció (Veny-Mesquida). Ja hem vist, però, que una característica d'aquestes imatges provinents de l'inconscient és la seva emergència deslligada, una irrupció de material que arriba de no se sap on $i$ que desinfla la infatuació i les pretensions de consistència, cohesió i coherència del pensament conscient. Si seguim Freud, sovint són, ultra això, la manifestació d'un molest vigia i censor intern.7

Reprenent el fil del nostre treball, volem argumentar que l'interès per la llibertat de les imatges hipnagògiques experimentada als inicis retorna en diferents moments creatius posteriors. Glòria Bordons ja ho ha assenyalat. En el cas d'aquest estudi hem seleccionat alguns poemes visuals nascuts de jocs amb les lletres de l'alfabet. Fet i fet, aquestes constitueixen un objecte tan familiar i fins i tot íntim per a un escriptor (l'agent de l'acte d'escriptura i el productor de literatura escrita) com ho són les paraules. No és estrany que esdevinguin, doncs, un motiu d'estranyesa si se les observa des de la posició insòlita que ofereix una distància crítica. D'aquesta talaia estant es pot fer conscient allò que, de tan proper com era, ens passava desapercebut.

\section{LA LLETRA COM A OBJECTE.}

\section{LA CARA DOBLE DE LA LLETRA}

A continuació analitzem algunes produccions de Brossa molt posteriors a les primeres provatures amb les imatges hipnagògiques. En concret, els poemes visuals en què experimenta amb les lletres de l'alfabet. Aquest salt queda justificat per l'horitzó i els límits del nostre treball. Volem remarcar el fet que les característiques de discontinuïtat i llibertat que caracteritzen les imatges hipnagògiques i oníriques (processos inconscients) si les comparem amb l'ús habitual, travat, dels mots per part del pensament, es reiteren en el tractament posterior de les lletres. Tant les unes com les altres comparteixen una mateixa voluntat de ruptura i de sorpresa. Però si les primeres només trabucaven la llengua, 
les segones afecten també la grafia. I aquest fet ens obliga a dirigir al text escrit una mirada tan nova com insòlita.

El nostre abecedari és un sistema d'escriptura desenvolupat a través dels segles en un domini cultural circumscrit. Tot i que aquesta correspondència és, per força, més o menys imperfecta i inexacta, apunta al propòsit ideal de fer equivaldre un signe escrit $i$ un so. Altres àrees culturals utilitzen uns sistemes gràfics diferents del nostre: ideofonogràfics, sillàbics o consonàntics. Hi ha fins i tot un percentatge força elevat de llengües sense cap mena d'escriptura.

A l'entrevista ja citada amb Jordi Coca, el poeta fa un comentari interessantíssim, que ha estat sovint citat: "En aquell moment jo era un ull que veia però que no mirava. I tot el procés ha estat de reeixir a saber mirar, reeixir en l'empresa de penetrar les coses" (24). Aquest viratge del veure al mirar (de la fascinació hipnòtica a la lecto-escriptura analítica) és el pas que van dur a terme diverses civilitzacions antigues (Mesopotàmia, Egipte antic, Xina, etc.) en el camí d'invenció d'una escriptura. El lema ètic de Brossa — capgirat per nosaltres en "caminar i oblidar"aprofundeix, a parer nostre, en aquesta mateixa direcció.

Brossa i Freud van compartir una mateixa passió per les cultures antigues de l'Orient mitjà i per les velles escriptures. Lacan no va ser una excepció a aquesta fília i va ser fidel a aquest apassionament del seu antecessor per la història de l'escriptura. La va enriquir fins a incloure-hi la xinesa i la japonesa. L'any 1957 va escriure un treball amb un títol ben evocador per al nostre estudi: "L'instance de la lettre dans l'inconscient ou la raison depuis Freud" I en el decurs dels anys 70 , aquest interès per la lletra no va fer sinó augmentar. ${ }^{8}$ Queda clara, doncs, la rellevància de la qüestió de la naturalesa de la lletra per a la teoria i, encara més, per a la pràctica psicoanalítica. Pel que pertoca al nostre estudi, ens servirà de guia, de manera molt especial, el llibre de Gerard Pommier, Nacimiento y renacimiento de la escritura (1996).

Què ens diu la teoria psicoanalítica sobre l'escriptura? Afirma que l'impuls que la genera, com també la seva permanència constant i activa, és una resposta del subjecte a les exigències del gaudi pulsional. Cada un de nosaltres, per tal de ajustar-se a les condicions i restriccions que determina el nostre nínxol cultural particular (que correspon a una societat que empra llengües escrites), ha d'aprendre a llegir i escriure. Individualment, hem d'inventar de cap i de nou la clau que ens ha de permetre l'accés al gaudi articulat (mediat) de la cadena analítica de sentit. Aquesta clau de l'escriptura sembla suggerida per aquest poema, molt conegut, de Brossa (Fig. 1).

Les lletres de l'alfabet modelen les dents (la contrasenya) de la clau. Quina porta obre? Ni més ni menys, com veurem a l'exemple següent, que la de la interpretació de les imatges oníriques, que són a l'origen de les primitives visons de l'art i dels primers pictogrames. La invenció històrica i individual de l'escriptura 


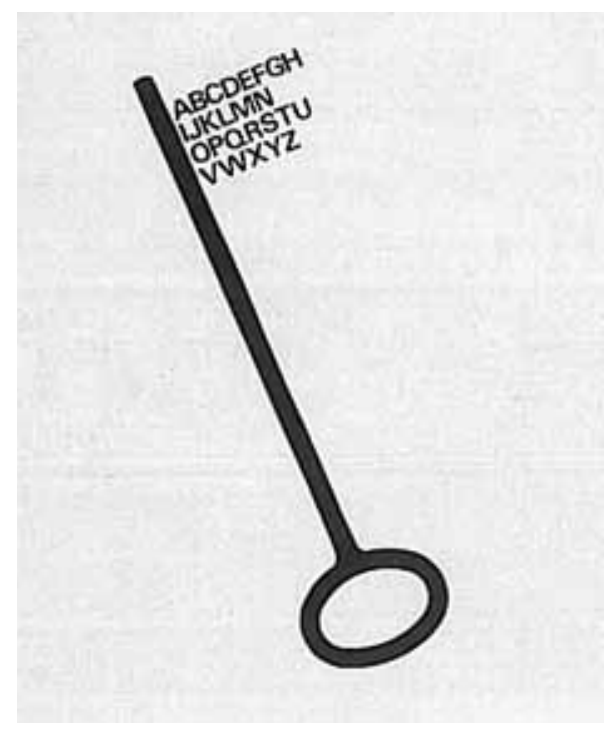

Fig. 1. "Poema visual” (concebut el 1971, realitzat el 1982) (Joan Brossa o la revolta poètica 146).

sorgeix, segons la hipòtesi psicoanalítica desenvolupada per Pommier, de les imatges nocturnes.

Per tal d'interpretar un somni, el primer esglaó és considerar-lo un missatge portador de significat. Aquest va ser el pas transcendent de Freud, per mitjà del qual va alliberar el fenomen oníric de la seva marginalitat científica. Ni que només sigui per això, La interpretació dels somnis té un valor incalculablement superior a qualsevol dels volums publicats per Maury, Guyon o Leroy. Al rerefons hi ha una aposta arriscada a favor d'un saber que s'amagava rere les supersticions populars i la pràctica dels endevins de l'antigor. Enmig de tanta faramalla hi va intuir un nucli de raó i va fer-hi confiança. S'entén la segona part del títol que hem citat de Lacan “[...] et la raison depuis Freud". La descoberta freudiana brinda una explicació racional a unes manifestacions de llenguatge ("una altra manera de parlar", segons l'autor) fins aquell moment incomprensibles o defectuosament interpretades per un pensament anterior a la ciència. "Pintoresc", va dir-ne Brossa.

El segon pas de Freud va ser trobar el mètode de lectura adequat a aquesta escriptura feta amb imatges (visuals o sonores). Va acudir, aleshores, als epigrafistes i va redescobrir el mecanisme del rebus. Aquest procediment és present, d'una manera o altra, en qualsevol invenció històrica d'una escriptura. Breument, consisteix en la renúncia al gaudi visual immediat provinent d'una imatge aillada (un pictograma, per exemple: 母 'mare', 山 'muntanya', 川 'riu') i la seva substitució per un valor sonor, extret de la llengua parlada: haha, yama, kawa. ${ }^{9}$ La lletra ja no representa aleshores un objecte sinó un segment o un mot sencer d'una llengua 
particular. Hem passat de la immediatesa de la percepció a la intromissió del filtre mediador de la paraula.

A la Xina, per posar un exemple, existia un pictograma per a la paraula "planta". Com que el verb "venir" era homòfon de "planta", es va emprar el pictograma corresponent al vegetal per representar el verb de moviment (Keightley 170). No existia cap vincle semàntic entre els dos vocables, però aquest passatge a un valor sonor va permetre la generació d'un sistema d'escriptura capaç de reproduir la parla d'una llengua determinada. L'aplicació del mecanisme del rebus exigeix esborrar la imatge visual com a condició prèvia. Entremig, passem d'un estadi de percepció a un estat fugisser de ceguera semàntica. En aquest destret, el signe, ara buit de significació, s'enllaça a l'únic que li resta: el valor sonor que li brinda una paraula d'una llengua concreta. En endavant servirà d'unitat gràfica (com si fos el revers del recorregut d'una cinta de Moebius): una baula, entre altres, del collar que escriu la cadena articulada de la parla. Aquest és el franqueig pulsional que ha de travessar cada nen en el decurs del procés d'adquisició individual de l'escriptura. Podem il·lustrar el mecanisme del rebus amb una producció brossiana:

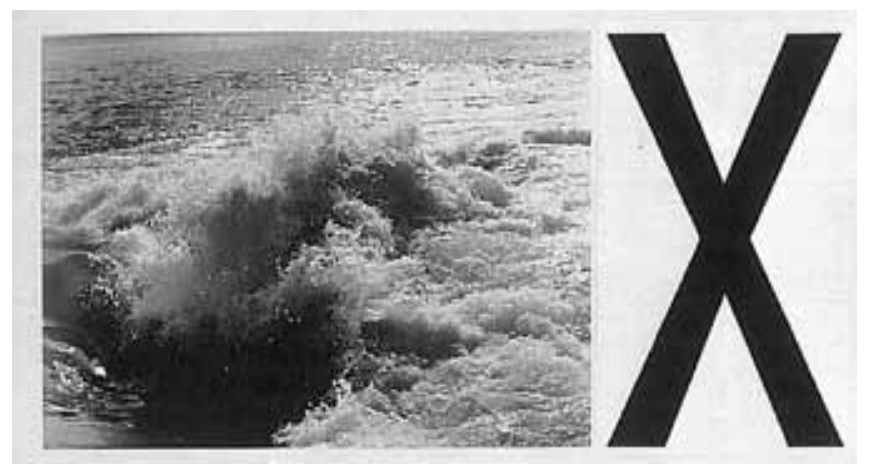

Fig. 2. “Oda a Marx” (1983) (Joan Brossa o la revolta poètica 145).

Per tal de llegir el missatge, cal que ratllem el valor visual de la representació i que el substituïm pel valor fonètic particular que li atribueix la llengua catalana: "mar". I fixem-nos en un altre detall: la fotografia-imatge del mar és un mot independent. Però en traduir-lo a un valor fonètic, la cadena "mar" no tan sols es buida del sentit primer sinó que deixa de tenir un significat independent. En endavant, només li és possible de crear un novell sentit a condició d'encadenar-se a una altra lletra. D’altra banda, fixem-nos en el fet que el nou mot, "Marx", no té res a veure, en principi, amb “mar”. Aquest exemple ens pot ajudar a entendre per què Freud i, amb més claredat, Lacan, refusen la interpretació simbòlica. Un comentari més: l'experiència psicoanalítica ens confronta amb casos com el que ara descriurem: algú podria estar parlant de Marx i de sobte sobrevenir-li una visió 
marina obsessiva (una manifestació de la presència de l'altre cantó de la cinta de Moebius).

A l'inici vam ser l'objecte de complaença del gaudi matern (immediat). Partim d'allí com a exiliats i la terra de promissió que ens acull és la llengua social i compartida, la que de manera tan magistral va teoritzar Ferdinand de Saussure tot reprenent els descobriments dels filòsofs estoics. La coerció cultural (el llenguatge) -que afecta la totalitat de l'espècie-, s'actualitza per a cada un de nosaltres. La renúncia inicial (a esdevenir l'objecte del gaudi matern), determinada per la submissió salvífica (tot i que decebedora i dolorosa) a la llengua, es correspon amb el concepte de "repressió original" de Freud i amb el de "tabú de l'incest" de l'antropologia. Es reitera cada vegada que fem ús de la paraula, del pensament o de l'escriptura. És a dir, sempre que reeixim a servar la flama de la llum de la consciència.

El gaudi primer és hipnòtic, il-limitat: pot ser visual (fascinació per la mirada) o auditiu (fascinació per la veu). Mentre som obnubilats per l'una o l'altra - cosa que coneixen bé els hipnotitzadors-, som incapaços de llegir, de pensar o d'observar. A propòsit del gaudi de la bellesa, Pommier diu que ens alleuja retrobar, gràcies a la percepció subjectiva d'alguns objectes de l'entorn, la imatge perduda del nostre $\cos$ (202). Potser per això la imatge del bou, mirall de bravura sense esquerdes ni fissures, és a l'origen de la primera lletra del nostre alfabet. Brossa s'ha complagut a representar-la en múltiples ocasions, fins i tot en la seva posició invertida, que recupera la figura d'origen (Moore 78):

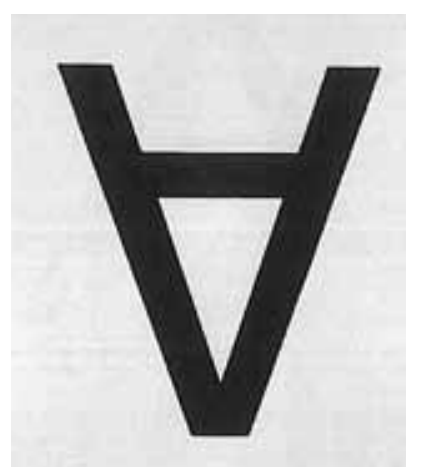

Fig. 3. "Cap de bou" (concebut el 1969, editat el 1982) (Joan Brossa o la revolta poètica 196).

La forma i disposició de les ales d'una papallona (per triar un exemple) podria haver donat lloc a la invenció d'un pictograma que signifiqués "ales" i que, gràcies a l'aplicació del mecanisme del rebus, hagués perdut el seu valor semàntic i hagués passat a representar la unitat sonora "ales": 


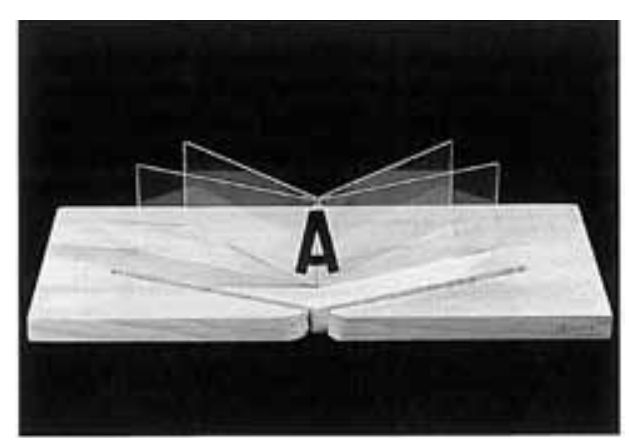

Fig. 4. "A d'Alas” (1990) (Brossa Tria de poemes 104).

Aquesta unitat podria, a continuació, entrar a formar part de paraules com "ales-hores" (ens imaginem una seqüència onírica amb l'escena d'unes ales de papallona i un rellotge de sorra?); o "c-ales" (a la manera d'“Oda a Marx", es podria escriure amb una "c" i la imatge de les ales. Hi llegiríem 'platges' o 'diners'). ${ }^{10}$ L'interès per les lletres és una intel-ligent reactualització de l'inicial interès per les imatges hipnagògiques.

És evident que no hem esgotat les interpretacions possibles dels poemes com tampoc de les línies evolutives de Brossa. No és aquesta, d'altra banda, la nostra pretensió. Fet i fet, la complexitat d'una obra artística exigeix l'intent d'afavorir un ventall de lectures que, ben conjuminades, construeixen una significació polifònica. La teoria psicoanalítica pot aportar-hi la consideració del treball d'escriptura com a procés de sublimació (que podria generar el bon oblit). Aquest, però, sempre deixa restes de brossa que no es reciclen: les imatges deslligades. I aquesta romanalla retorna incansable, generada implacablement pel mateix treball sublimatori. D'aquí que la idea d'una civilització ideal amb un absolut domini de les passions salvatges sigui inconcebible.

En tot cas, i pel que fa a l'escriptura, el seu bressol són les lletres rebus dels somnis que els nostres avantpassats van esforçar-se a traçar damunt alguna superfície de suport, sigui la paret rugosa d'una cova, sigui una tova d'argila. Les primeres lletres són lliures, dinàmiques, cinètiques (recordem las característiques amb què les defineix el llibre de Soria y Hernández). De la mateixa manera que passa amb les imatges hipnagògiques, tampoc elles fan cadena, no estan destinades, d'antuvi, a la construcció d'una significació. Però no per això són menys reals. El que succeeix és que el nostre pensament racional les margina i, en deixar de prestar-hi atenció, les oblidem.

En reduir-les a un valor sonor asemàntic (una " $\mathrm{A}$ " ignorant del seu origen de cap de bou), les lletres ens allunyen de la immediatesa de la percepció. Aleshores esdevenen signes indirectes, és a dir, representants de paraules. A més, igual que passa amb el signe lingüístic, ja no valen per elles mateixes, necessiten unes altres 
lletres per poder recuperar la funció i la capacitat de significar. En el procés, perden la seva naturalesa primera d'autonomia, de força i de llibertat. Hem oblidat el sentit primitiu de la imatge del mar quan la trobem en paraules com "re-mar", "ri-mar" o "Mar-x".

El lema brossià de "caminar i oblidar" evoca, al nostre entendre, aquest franqueig que suposa l'accés a l'escriptura. Els mots "oblidar" (efecte de l'escriptura) i "caminar" (escriure-sublimar) descriuen una travessia pulsional. De la terra d'exili estant, l'aparició sobtada de les lletres ens fa reviure la nostàlgia i els moments de paüra que, juntament amb els soldadets i les nines, vam deixar enrere en créixer. Són inscripcions que ens obsessionen i ens fascinen perquè, de tan primerenques, mai no les vam saber assimilar.

Si els elements que realment importen són més enllà de la comprensió aparent, com hem de traduir? A l'apartat dedicat a la traducció de Brossa, "Entenem el poeta? La impossibilitat de la traducció", London escriu:

Com si fos el resultat de la seva recerca sobre la construcció de la llengua verbal, Brossa acaba oferint-nos les seves unitats més petites que són encara reconeixibles. És a dir, les lletres.... Valorar la lletra com a imatge confon tota la dialèctica entre llengua verbal $\mathrm{i}$ imatge perquè els dos elements no es poden separar. Recordem que les lletres no ideogràfiques (com les lletres llatines) ja no representen imatges visuals (com el xinès) sinó que formen conceptes sonors: són realment iconoclastes en el sentit etimològic dels mots "literalment" i "iconoclastes", perquè destrueixen la imatge amb lletres i tendeixen a transmetre sons. Amb lletres hom pot construir paraules, però quan Brossa es concentra exclusivament en les lletres, les treu de qualsevol paraula, o conte: són imatges, però no poden ser ideogrames perquè són encara lletres llatines. (164-65)

El que London planteja com dos realitats solapades nosaltres ho hem explicat com una mateixa instància conformada a la manera d'una cinta de Moebius: per un cantó és lletra plena, és a dir, aillada, immediata, visual i sonora (com, per exemple, la imatge hipnagògica); i de l'altre, és lletra sonora, mediata, asemàntica $\mathrm{i}$, en acabat, mancada. Això darrer s'ha d'entendre en el sentit que, igual que passa amb els fonemes, necessita altres lletres per recuperar la capacitat de significar. Cal abandonar la visió fascinada del mar per accedir a l'escriptura de "re-mar", "ri-mar" o "Mar-ia".

Un cop més, la iconoclàstia assenyalada per London té a veure amb la pulsió i amb la història de l'escriptura. La tesi de Pommier, lector de Freud i de Lacan, és que la invenció de l'alfabet guarda una relació històrica amb la repressió del gaudi de la imatge que va imposar el monoteisme a les religions politeistes de les cultures de l'Orient mitjà.

Encara volem estirar un xic més del fil de les intuïcions brossianes. L'alfabet està format per dos elements distints, consonants i vocals. Les segones no necessiten les 
primeres per esdevenir matèria sonora. Les consonants, en canvi, són mudes en absència de les vocals. És a dir, són indefectiblement lletres lligades, mentre que, a les vocals, els és possible prescindir de l'altra meitat de l'alfabet. Això les apropa a la llibertat de les imatges hipnagògiques (una coincidència amb les escriptures semítiques, que es limiten a escriure les consonants. Les vocals van ser foragitades de l'escriptura per l'imperatiu iconoclasta). Fixem-nos en el poema "Muntanya":

\section{$\underset{\text { M NT NY }^{\text {A }}}{\text { A }}$}

Fig. 5. (Brossa Poemes visuals s.p.).

Les vocals són les úniques lletres capaces d'emancipar-se de la cadena i enlairar-se. Gaudeixen de la llibertat inusitada i sorprenent de les imatges desencadenades provinents de l'inconscient. La mateixa paraula "Muntanya" s'enfila, altívola, cap al cel de la pàgina. Un darrer exemple:

$$
\text { runt }
$$

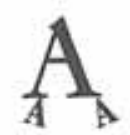

\section{B RCELON}

Fig. 6. "Imant" (Brossa Poemes visuals s.p.). 
En aquest poema una lletra "A" aillada arrossega les "A" encadenades que, conjuntament amb d'altres lletres, escriuen el nom de la ciutat comtal. La repressió original, tal com la va definir Freud, actua de la mateixa manera. És la lletra que mai no podrem escriure i que atrau tots aquells elements que directament o indirectament l'evoquen. En aquest cas, les dues "A" de "BARCELONA". A un nivell molt més conscient, la censura produeix un efecte similar. L'ocultació primera obliga a fer renovats encobriments per aturar el cadàver que sempre és a punt de rodolar fora de l'armari on ha estat amagat.

\section{CONCLUSIONS}

Aturem en aquest punt el nostre recorregut a través de les experimentacions poètiques de Brossa i la seva relació amb l'inconscient i la pulsió. Només afegirem, a tall de conclusió i amb la voluntat de circumscriure una recopilació de les idees exposades, una mena de llistat de síntesi:

1) L'esperit que va impulsar les experimentacions inicials amb les imatges hipnagògiques no va ser mai abandonat $\mathrm{i}$ va retornar en produccions posteriors. Per exemple, en els poemes visuals caracteritzats per la manipulació de les lletres.

2) La lletra té dues cares, la lligada i la lliure. Aquesta darrera suposa el retorn de la llibertat de la imatge hipnagògica. Mobilitzada per l'angoixa, l'escriptura pot ser un acte sublimatori (no sempre és així).

3) Una pregunta: fins a quin nivell de profunditat Brossa va llegir Freud i va tenir contacte amb coneixedors de la seva obra? El poeta va trobar la inspiració en els seus antecessors: Mallarmé, Junoy, Salvat-Papasseit, Foix, el lletrisme francès, la poesia concreta i el moviment Noigandres a Brasil i d'altres (London 161). Gairebé tots, tanmateix, han estat influits, directament o indirecta, per l'obra de Freud. I aquesta, no ens parla tothora de la relació que s'estableix, més enllà de la nostra voluntat, entre la paraula, l'escriptura i l'escena (això ens duria a un altre estudi) amb el gaudi del cos?

\section{NOTES}

Aquest article s'inscriu en el Grup d'Estudi de la Traducció Catalana Contemporània (GETCC, 2009, SGR 1294), reconegut i finançat per l'Agència de Gestió i Ajuts Universitaris de la Generalitat de Catalunya, i en el projecte "La traducción en el sistema literario catalán: exilio, género e ideología (1939-2000)", amb el número de referència FFI2010-19851-C02-01, finançat pel Ministerio de Ciencia e Innovación. 
1 És curiós que no ho fes també en castellà. Ortega i Gasset va impulsar l'edició de totes les obres de Freud a l'editorial Biblioteca Nueva i entre 1922 i 1934 van sortir fins a 17 volums (s'ha de tenir en compte que Freud encara era viu i seguia escrivint). El traductor, José Luís López Ballesteros, va fer una traducció excel·lent (si acceptem els límits de qualsevol traducció), que va rebre l'elogi del mateix Freud l'any 1923 i que segueix sent la preferida de molts psicoanalistes. Evidentment, el projecte editorial, així com la introducció de la psicoanàlisi a Espanya, va ser estroncat per la guerra civil. Les traduccions franceses d'aquells anys no estaven a l'alçada de les versions de López Ballesteros, ni en extensió ni en qualitat.

2 La interpretació dels somnis és, juntament amb Tres ensayos para una teoría sexual de 1905, l'obra en què Freud va introduir més modificacions, provinents de noves aportacions d'altres investigadors, al llarg de la vida. Justament, va considerar les imatges hipnagògiques de Herbert Silberer com una de les poques aportacions valuoses a afegir al que ja havia exposat a propòsit dels somnis a la primera edició de 1899 .

3 Fundada per Freud i el psiquiatre suís Eugen Bleuler, aquesta publicació va deixar d'existir l'any 1913, després del conflicte entre Freud i Jung. El títol del text de Silberer surt citat al Dictionnaire international de la psychanalyse d'Alain D. Millola (1585-86).

4 El jo és una instància de desconeixement, d'estructura paranoica: "Veu però no mira", com diria Brossa. Tot l'esforç s'adreça, doncs, a "saber mirar"... més enllà del jo i els seus miralls. Magritte va pintar quadres que encaixessin al marc de la finestra. Si ens permeteu la metàfora, el que veu el jo (consciència ingènua) és senzillament la tàpia del quadre.

5 Un interessant punt de partida per a una explicació psicològica dels poemes escènics.

6 Tot i que a La interpretació dels somnis hi ha una certa ambigüitat al respecte.

7 Pel que fa a les citacions de Freud, som conscients d'haver deixat molts caps per lligar. Tenim l'esperança que el fet de deixar-los a la vista, tot i que no treballats, sigui un esperó per a recerques i reflexions posteriors. Els límits que ens hem imposat en aquest estudi ens impedeixen anar més enllà.

8 Vegeu, per exemple, l'article "Lituraterre" aparegut a la revista Littérature, 3 (1971), p. 3-10. A més de les referències a l'escriptura japonesa, hi trobem un reguitzell de neologismes a la manera de Joyce.

9 Permeteu la llicència de triar exemples $a d$ hoc, extrets de l'escriptura japonesa.

10 Aquesta doble cara de la lletra és present en qualsevol text. En una frase com "cales aleshores paradisíaques", la repetició del mot "ales" podria produir una emoció que, de tan viva, s'arribés a transformar en la visió hipnagògica d'un vol de papallones. Aquesta circumstància posa en evidència l'engany permanent del llenguatge. No es tractava de comprendre la significació evident de la frase escrita sinó la repetició involuntària, i no per això innocent, de la lletra "ales". Assajos semblants, tan extraordinàriament poètics com arriscadament experimentals, van ser duts a la pràctica cap al segle VI pels antics escribes japonesos, que van inventar una escriptura anomenada manyôgana, en desús des de fa segles, que aprofitava els valors sonors dels logofonogrames xinesos. 


\section{REFERÈNCIES}

Bordons, Glòria. “Joan Brossa i el surrealisme”. Surrealismo y literatura en España. Ed. Jaume Pont. Lleida: Universitat de Lleida, 2001. 301-22.

Brossa, Joan. El Saltamartí. Capellades (Barcelona): Ocnos/Llibres de Sinera, 1969.

-. Poesia rasa. Tria de llibres (1943-1959). Barcelona: Ariel, 1970.

-. "Model de fruita". Cappare. Barcelona: Proa, 1973.

-. Poemes visuals. Barcelona: Edicions 62, 1975.

—. "La bola i l'escarabat". Ball de sang. Barcelona: Crítica, 1982.

-. Poemes hipnagògics. Ed. de Ricard Salvo. Barcelona: OEIA experimental, 1995.

-. Tria de poemes conversables; Tast de poemes objecte. Barcelona: Barcanova, 2002.

- Prosa completa i altres textos. Ed. a cura de Glòria Bordons. Barcelona: RBA, 2013.

Coca, Jordi. Joan Brossa. Oblidar i caminar. Barcelona: La Magrana, 1992.

Freud, Sigmund. "Introducción al narcisismo". Obras completas. Vol. VI. Trad. de Luís López-Ballesteros. Madrid: Biblioteca Nueva, 1974. 2017-33.

—. "La interpretación de los sueños". Obras completas. Vol. II. Trad. de Luís LópezBallesteros. Madrid: Biblioteca Nueva, 1974.

-. "Sobre la psicogénesis de un caso de homosexualidad femenina". Obras completas. Trad. de Luís López-Ballesteros. Vol. VII. Madrid: Biblioteca Nueva, 1974. 2545-62.

- . "Tres ensayos para una teoría sexual”. Obras completas. Vol. IV. Trad. de Luís LópezBallesteros. Madrid: Biblioteca Nueva, 1974. 1169-1237.

—. "Tratamiento psíquico (tratamiento del alma)". Obras completas. Vol. I. Trad. de José Luís Etcheverry. Buenos Aires: Amorrortu, 1985. 111-32.

"Herbert Silberer". Dictionnaire international de la psychanalyse. Ed. Alain de Mijolla. Vol. II. París: Calmann-Lévy, 2002.

Joan Brossa o la revolta poètica. Ed. Manuel Guerrero. Barcelona: Generalitat de Catalunya, Departament de Cultura/Fundació Joan Brossa/Fundació Joan Miró, 2001.

Keightley, David N. "Los orígenes de la escritura en China: escrituras y contextos culturales". Los orígenes de la escritura. Ed. de Wayne M. Senner. Trad. de St. Mastrángelo. Madrid: Siglo XXI, 1992. 157-84.

Lacan, Jacques. "L'instance de la lettre dans l'inconscient ou la raison depuis Freud". Écrits. Paris: Seuil, 1966. 493-528.

—. "Position de l'inconscient". Écrits. Paris: Seuil, 1966. 829-50.

—. "Lituraterre". Littérature, 3, 1971.

-. Le Seminaire. Livre XI. Les quatre concepts fondamentaux de la psychanalyse. Ed. Jacques-Alain Miller. Paris: Seuil, 1973.

Moore Cross, Fran. "La invención y el desarrollo del alfabeto". Los orígenes de la escritura. Ed. Wayne M. Senner. Trad. de S. Mastrángelo. Madrid: Siglo XXI, 1992. 76-88.

Lévi-Strauss, Claude. El pensament salvatge. Trad. de Miquel Martí i Pol. Barcelona: Edicions 62, 1985.

London, John. Contextos de Joan Brossa. L'acció, la imatge i la paraula. Barcelona: Edicions UB, 2010.

Oller, Dolors. "La paradoxa virtual a Joan Brossa (paradoxa, ironia i anacronia)". La revolta poètica de Joan Brossa. Barcelona: Departament de Cultura de la Generalitat de Catalunya, 2003. 39-47. 
Permanyer, Lluís. Records. Brossa x Brossa. Barcelona: La Campana, 1999.

Pommier, Gerard. Nacimiento y renacimiento de la escritura. Trad. d'Irene Agoff. Buenos Aires: Nueva Visión, 1996.

Sacristán, Manuel. "La pràctica de la poesia (Joan Brossa)". Poesia Rasa. Tria de llibres (1943-1959). Barcelona: Ariel, 1970. 9-27.

Salvo, Ricard. "La imatge hipnagògica". Joan Brossa. Poemes hipnagògics. Ed. de Ricard Salvo. Barcelona: OEIA experimental, 1995.

Santamaria, Vicent. "Foix, Dalí i les imatges hipnagògiques". Els Marges 63 (1999): 7-19.

Soria y Hernández, Teodoro D. Lecciones de psicología. 4a. ed. Madrid: Imprenta de Salvador Quemades, 1935.

Veny-Mesquida, Joan R. "J.V. Foix: L'avantguarda eclèctica”. Surrealismo y literatura en España. Ed. Jaume Pont. Lleida: Universitat de Lleida, 2001. 211-20. 